\title{
RESULTS OF THE COMMERCIALISATION OF SCIENTIFIC RESEARCH IN THE LIGHT OF EXPERIENCE Gained at the Nicolaus Copernicus University Centre for TeChNOlogy Transfer
}

\author{
Paweł Matlakiewicz ${ }^{1)}$, Piotr Matuszak ${ }^{2)}$, Grzegorz Grodzicki ${ }^{2)}$ \\ 1) Centre for Technology Transfer Nicolaus Copernicus University sp. z o.o. [Ltd.] \\ 2) Bionitec Sp. z 0.o. [Ltd.], 87-100 Toruń, Poland
}

\section{ABSTRACT}

The statutory mission of a university, in addition to the creation of scientific knowledge and education, lies in the cooperation with the economic sector through the transfer of knowledge and technology. The effectiveness of this process directly affects the affluence of any given State's economy. Owing to the new amendments to the Act on Higher Education, many barriers that hinder commercialisation of knowledge in Poland have been brought down. Nicolaus Copernicus University in Torun sets an excellent example in this respect having established a special purpose entity, which has already managed to set up thirteen spin-off companies in just 18 months.

Key words: commercialisation, spin-off companies, technology transfer, Nicolaus Copernicus University.

ARTICLE INFO

PolHypRes 2016 Vol. 54 Issue 1 pp. 37-40

ISSN: 1734-7009 elSSN: 2084-0535

DOI: $10.1515 /$ phr-2016-0005

Pages: 4, figures: 0 , tables: 0

page www of the periodical: www.phr.net.pl

Publisher

Polish Hyperbaric Medicine and Technology Society
Informing article

Delivery date: $05.07 .2015 \mathrm{r}$.

Date of approval for print: $15.09 .2015 \mathrm{r}$. 


\section{INTRODUCTION}

Article 4 of the Act on Higher Education [1] outlines the statutory mission of a school of higher education. In addition to 'discovering and transferring the truth through conducting research and educating students' it also involves 'cooperating with the socialeconomic environment, especially in the scope of conducting scientific research and development works for the benefit of business entities' [2]. The legislator indicates that the cooperation should be conducted in separate forms of activity, including the formation of a special purpose entity [3].

In principle, business entities act on a commercial basis. A commercialisation process in a broad sense of the term consists in channelling a certain scope of scientific activity of a university into the benefit of companies that operate on the free market. The legislator is thus striving to achieve a synergy between the scientific activity of a school of higher education, primarily funded from the state budget, and companies whose income in part adds to the public purse.

On account of this simplified summary of costs and revenues, the effective application of the commercialisation of scientific knowledge is in the interest of the entire society, and directly affects the level of its affluence. The cooperation between the university and the company has come up against many organisational, as well as mental barriers on both sides [4].

Describing these barriers lies well beyond the framework of this article, yet it is important to note that the legislator has sought a way out of this deadlock in the solutions operating in Western Europe for the last twenty years. For this reason the establishment of special purpose entities by universities was indicated as a tool that genuinely breaks barriers in the cooperation between a school of higher education and business entities.

The last two amendments to the Law on Higher Education aimed to establish a legal framework for the process of commercialisation of scientific knowledge that was provided by universities. On legislative grounds the process was divided into two types of activities: direct and indirect commercialisation [5]. The former process consists in the sale or licensing of intellectual property belonging to a school of higher education, which in fact is the patent claims or know-how presented in writing. In order to coordinate this process, universities may set up special institution-wide units called centres for technology transfers.

However, it must be here emphasised that selling or licencing patents outside of technical universities is not easy, as market-wise the majority of solutions that are created in schools of higher education cannot pass for complete products, but they are just elements or even only ideas for making a product. It appears that this does not fully satisfy the market needs of companies as they would prefer to be able to estimate possible profits from the implementation of particular products that are based on scientific knowledge. Indirect commercialisation is the second form of scientific commercialisation. In essence, it consists in the forming of spin-off companies bythe special purpose entity.

In order for the university to apply this form of commercialisation, it must establish a special purpose entity with the university as the sole shareholder. It is then only that company which can establish 'daughter companies' with other entities, these falling under the category of spin-off companies ${ }^{1}$. Owing to the 'Spin-Tech' project run by the National Centre for Research and Development, this commercialisation path has been taken up by Nicolaus Copernicus University among others. In January 2014 a special purpose entity by the name of Centrum Transferu Technologii UMK sp. z o.o (The NCU Centre for Technology Transfer) was established.

For reasons of clarity as regards the division of the internal process of commercialisation, it must be added that the legislator provided for the possibility of a contractual transfer of direct commercialisation to the university's special purpose entity, and this is exactly the solution applied at NCU.

After nearly two years of its activity, the NCU Centre for Technology Transfer has shares in thirteen spin-off companies, which operate in the fields of environmental protection (Bionitec sp. $\mathrm{z}$ o.o., Bacto-Tech sp. z o.o., Instytut Technik Sensorycznych sp. z o.o. (Institute of Sensory Techniques)); drone technologies and IT (Cybernova sp. z o.o., Image Citadel sp. z o.o. GnosiGIS sp. z o.o., eEditing Ideas for Research \& Teaching Transfer sp. z o.o.); medicine (Centrum Innowacji Medycznych Copernicus sp. z o.o., (the Copernicus Centre for Medical Innovations), Nano-implant sp. $\mathrm{z}$ o.o.), cognitive science (PerKog Technologies sp. z o.o., Idea Spin sp. z o.o.); and physics (Carbotec sp. z o.o., LumiDatis sp. $z$ o.o.). Except for the capital and organisational share of the special purpose entity, 'daughter companies' also comprise: scientists employed by NCU; entrepreneurs with knowledge and market position in the area of activity of the newly created partnership, investors and other competent people, predominantly NCU graduates.

The range of the listed entities obviously does not concern each and every one of the thirteen companies. First experiences of the NCU Centre for Technology Transfer indicate that indirect commercialisation is more effective than its direct counterpart. Scientific knowledge that is indirectly transferred to the economy, does not necessarily have to provide what is considered in market terms to be a readymade completed product.

The completion of the project and its market entry may be effected without any barriers within the spin-off company itself and not at the university. What is more, in the present market situation, the amount of capital to be involved in the completion of an innovative product that is based on scientific knowledge exceeds the number of commercialised ideas at Polish universities.

In order to better understand these forms of commercialisation let us look closely at one of the first spin-off companies, Bionitec Sp. z o.o. The company was established by the NCU Centre for Technology Transfer and two originators, the Prometheus Foundation which is an innovation broker and the co-investor.

The scientific knowledge that was brought in by the Centre and the originators in the form of a know-how, together with source codes as regards to innovative methods of environmental biomonitoring, were based on the analysis of a sequence of data points, known as a time series (a series of measurements made over a time interval), related to the shell movement of Dreissen polymorpha mussels under the influence of different chemical substances present in water.

All the copyrights from the time of patent application became property of the company. 
The foundation together with the co-investor ensured the financial contribution that was required for the commercialisation of the scientific idea. Most of the resources come from the Innovative Economy Operational Programme, Measure 3.1 Initiating of innovative activity managed by the Polish Agency for Enterprise Development. The next step was to appoint a Supervisory Board and the Board of Directors by selecting members from among owners, including the originators who contributed the necessary know-how. Bionitec was entered into the National Court Register as of 4 August 2015 under the entry number 0000564784.

Since then it has been running a second stage of the commercialisation process of the possessed knowledge in close collaboration with the Department of Biology and Environmental Protection, the Department of Mathematics and Computer Science and the Department of Physics, Astronomy and Applied Computer Science of Nicolaus Copernicus University in Toruń, as well as with schools of higher education in Koszalin, Poznań, Olsztyn, Gdynia and Kraków. Bionitec is primarily engaged in the development of biomonitoring techniques with the use of mussels, supporting environmental protection through autonomous eco-drones, and recently it established cooperation with a company from Poznan in the scope of ecological barriers used for protecting swimming sites at lakes against the formation of Cyanobacterial blooms.

More information on the main activity of the company can be found in the article 'Biomonitoring of inland and inshore waters with the use of Dreissena polymorpha mussels' published in the 3 issue of the magazine 2015 year.

\footnotetext{
${ }^{1}$ It needs to be added that spin-off companies may be created without the involvement of the special purpose entity.
}

\section{BIBLIOGRAPHY}

1. Ustawa z dnia 27 lipca 2005 roku Prawo o szkolnictwie wyższym (tekst jedn. Dz U z 2012 poz 572).

2. Ustawa $z$ dnia 27 lipca 2005 roku Prawo o szkolnictwie wyższym (tekst jedn. Dz. U. z 2012 poz. 572)

3. Jaworska M., Musiałkiewicz R., Tomaszewski P.:Spójność Przedsiębiorczości i Nauki. [Cohesion of Entrepreneurship and Science] Toruń, 2011. 55-63 ISBN: 978-83-928698-7-0.

4. Jaworska M., Musiałkiewicz R., Tomaszewski P.:Spójność Przedsiębiorczości i Nauki. [Cohesion of Entrepreneurship and Science] Toruń, 2011. 7-9 ISBN: 978-83-928698-7-0.

5. Ustawa z dnia 27 lipca 2005 roku Prawa o szkolnictwie wyższym (tekst jedn. Dz. U. z 2012 poz. 572 art.1 pkt 35-36)

Piotr Matuszak MSc.

Centre for Technology Transfer Nicolaus Copernicus University sp. z o.o. [Ltd.]

$$
\begin{aligned}
& \text { ul.Gagarina } 5 \\
& \text { 87-100 Toruń }
\end{aligned}
$$

e-mail: piotr.matuszak@bionitec.pl 